\title{
Anhydrobiosis in invertebrates
}

\author{
Masahiko Watanabe* \\ Laboratry of Insect Life-cycles and Physiology, National Institute of Agrobiological Sciences (NIAS); Tsukuba 305-8634, Japan
}

(Received 4 July 2005; Accepted 11 November 2005)

\begin{abstract}
Recent work on anhydrobiosis in invertebrates is reviewed. I introduce definition and classification of cryptobiosis, and review the distinctive features and extremely high stress tolerance of anhydrobiotic invertebrates. Most anhydrobiotic invertebrates have evolved various kinds of behavioral, morphological, physiological and physical adaptations to reduce water loss during induction of anhydrobiosis. Trehalose is known as a common compatible solute in anhydrobiotic organisms from unicellular organisms to invertebrates and higher plants. Trehalose may provide effective protection against desiccation because it has superior biochemical and physicochemical properties for stabilizing membranes and biomolecules including proteins and lipids. Recent work also indicates several possible kinds of molecules involved in induction of anhydrobiosis. The adaptations necessary for successful induction of and recovery from anhydrobiosis vary greatly among taxa of invertebrates. Understanding the diversity of anhydrobiosis in invertebrates would be a key to elucidate evolutionary scenarios in anhydrobiosis.
\end{abstract}

Key words: Anhydrobiosis; cryptobiosis; invertebrates; dehydration; trehalose

\section{INTRODUCTION}

Organisms have evolved various types of survival strategies against adverse conditions. Some species move away from sites with harsh conditions to conditions more favorable for growth and reproduction, as in migratory butterflies and locusts (Dingle, 1996). On the other hand, most organisms must cope in the same place with adverse conditions such as low and high temperatures, limited food availability, high salt concentration, anoxia and dehydration (Danks, 1987).

Dehydration is one of the most serious stresses in both aquatic and terrestrial organisms. Water is the major component of living organisms. The average amount of body water in invertebrates is around $70 \%$ (from $17 \%$ to $90 \%$ ) and water makes up $95-99 \%$ of the total number of molecules (Edney, 1977; Hadley, 1994). Most organisms have only limited ability to survive water loss (Danks, 2000; Wharton, 2002b). Humans do not survive $14 \%$ loss of their body water and most organisms die when they lose $50 \%$ of the body water at the individual, organ or cellular level. Many desiccation- tolerant organisms have evolved mechanisms to inhibit water loss, but most of them die soon after the water content declines below a critical level, which varies greatly among species. On the other hand, some organisms are able to survive for an extended period even after they are almost completely dehydrated. This particular biological state is termed anhydrobiosis, a kind of cryptobiosis.

In this review, I provide an overview of studies on invertebrate anhydrobiosis from ecological, physiological, biochemical and molecular perspectives. This paper also considers recent researches concerning the biophysical property of cell membranes and biomaterials for protection against various stresses.

\section{DEFINITION AND CLASSIFICATION OF CRYPTOBIOSIS}

Leeuwenhoek (1702) observed inactive animalcules (tardigrades and rotifers) of an oval shape in dry sediments from the gutters of roofs of houses (Wright, 2001). The animalcules started moving shortly after coming into contact with water. A

*E-mail: masahiko@affrc.go.jp

DOI: 10.1303/aez.2006.15 


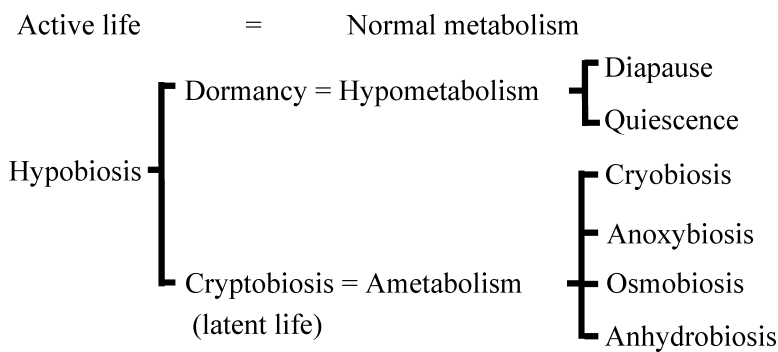

Fig. 1. Classification of hypobiosis based on the metabolic level. The definition in Keilin (1959) was modified based on the current concept of cryptobiosis.

similar ability to tolerate dehydration was reported in Needham (1743), Spallanzani (1776) and Doyère (1842). Such a phenomenon is termed cryptobiosis (latent or hidden life), and is defined as the state of an organism when it shows no visible signs of life and when its metabolic activity is hardly measurable, or comes reversibly to a standstill (Keilin, 1959). The state of cryptobiosis appears to be a distinctive biological phase of life history.

Cryptobiosis is one particular adaptation against environmental stresses, but should not be confused with diapause. The latter at the larval, pupal and adult stages is arrested development resulting from reduced hormonal activities, which may persist even when favorable environmental conditions come (Tauber et al., 1986; Danks, 1987). The most common environmental cues inducing diapause are unstressful factors such as photoperiod, whereas cryptobiosis responds to the stressful factors themselves. Keilin (1959) classified these adaptations based on the level of metabolic depression (Fig. 1). Diapause is a kind of hypometabolic state (dormancy) as well as quiescence [Keilin (1959) categorized hibernation and aestivation in dormancy, however these two terms reflect the season without specifying the type of developmental suppression]. Cryptobiosis is a generic term for ametabolism, and can be further divided into five categories based on the factors that induce it: cryobiosis (induced by freezing), thermobiosis (low and high temperatures), osmobiosis (extremely high osmolarity), anoxybiosis (lack of oxygen) and anhydrobiosis (lack of water).

\section{ANHYDROBIOTIC ORGANISMS THEIR DEVELOPMENTAL STAGES \\ AND}

Anhydrobiosis is the most common form of cryptobiosis, and anhydrobiotic organisms are able to survive almost complete dehydration; 95 to $99 \%$ of the water content is lost in many cases (Crowe et al., 1992; Danks, 2000). Such organisms are found in many taxa ranging from unicellular organisms to higher invertebrates and plants; plant seeds, vegetative tissues of higher plants (resurrection plants), yeasts, bacteria, fungal spores, protozoans, eggs of turbellaria, nematodes, rotifers, tardigrades, springtails, cysts of primitive crustaceans including the brine shrimp (Artemia salina) and larvae of a chironomid midge, Polypedilum vanderplanki (Schmidt, 1948; Vegis, 1964; Van Gundy, 1965; Clegg, 1967 1978, 1979, 2001; Crowe and Clegg, 1973; Crowe and Madin, 1974; Priestley, 1986; Wright, 1991; Crowe et al., 1992; Tomos, 1992; Potts, 1994; Sømme, 1995, 1996; Vertucci and Farrant, 1995; Ingram and Bartels, 1996; Ostran, 1998; Ricci, 1998; Chandler and Bartels, 1999; Potts, 1999; Seckbach, 1999; Alpert, 2000; Scott, 2000; Wharton, 2002b; Watanabe et al., 2004). One of the common features of these anhydrobiotic stages is limited size, and most of the invertebrates are less than $1 \mathrm{~mm}$. As an exception, larvae of $P o$. vanderplanki are large, and last-instar larvae which enter anhydrobiosis reach $7-8 \mathrm{~mm}$ in body length. No anhydrobiotic species have been found in vertebrates.

Crowe $(1971,1975)$ divided anhydrobiotic organisms into two major groups, based on the developmental stage in which cryptobiosis occurs. Members of one group enter anhydrobiosis only at an early ontogenetic stage (bacterial and fungal spores, seeds, eggs and larvae) and members of the other do so at any stage in their life cycle (tardigrades and rotifers etc.). This basic division of anhydrobiotic organisms appears to be generally accepted (Womersley, 1981). Anhydrobiotic organisms except for unicellular organisms can also be divided into two categories: in cysts of Artemia, for example, female parents produce either dormant cysts or free-swimming nauplii in response to the environmental conditions such as photoperiod and temperatures (Nambu et al., 2004), and to some extent prepare the molecules necessary for anhydrobiosis in the dormant cysts they deposit (Hochachka and Guppy, 1987). The dormant cysts can not enter anhydrobiosis again after embryogenesis proceeds (Hochachka and Guppy, 1987). In contrast, in larvae of a chironomid and in nymphs 
and adults of tardigrades, nematodes and rotifers, the parents do not affect induction of anhydrobiosis in their progenies at all, but individual progeny may reversibly switch their physiology and biochemistry between active (developmental) and anhydrobiotic phases.

\section{LONGEVITY AND TOLERANCE TO EX- TREME CONDITIONS}

Many anhydrobiotic animals can maintain viability for an extended period. Theoretically, metabolism and all chemical reactions should almost completely shut down during anhydrobiosis under conditions without humidity and oxygen. Anhydrobiotic tardigrades and rotifers recovered from a dry moss sample taken from an Italian museum after 120 years of preservation, although the individuals underwent 'quivers in several zones of its body' (Franceschi, 1948; Jönsson and Bertolani, 2001). Viable embryos of copepods were isolated from anoxic marine sediments 40 years old (Marcus et al., 1994) and from anoxic freshwater sediments after 332 years (Hairston et al., 1995). These resting embryos are assumed to be the state of anoxybiosis, a kind of cryptobiosis (Clegg, 1997).

More reliable demonstrations of the longevity of anhydrobiotic invertebrates after laboratory preservation are listed in Table 1. Steiner and Albin (1946) reported 39-year-survival in a nematode, Tylenchus polyhypnus. The longest records of recovery from the anhydrobiotic state are 17 years in insects, 16 years in crustaceans and 9 years in tardigrades and rotifers (Baumann, 1922; Clegg, 1967; Adams, 1985; Guidetti and Jönsson, 2002). The revival rate of a nematode, Anguillulina tritici,

Table 1. Longivity records in anhydrobiotic invertevrates

\begin{tabular}{|c|c|c|c|}
\hline Taxa & Species & Anhydrobiotic longivity & References \\
\hline Insecta & Polypedilum vandrplanki & 17 years & Adams, 1985 \\
\hline Crustacea & Branchinecta packardi & 16 years & Dexter, 1973 \\
\hline Crustacea & Artemia franciscana & 15 years & Clegg, 1967 \\
\hline Crustacea & Streptocephalus sealii & 15 years & Moore, 1979 \\
\hline Crustacea & Branchinecta mackini & 14 years & Dexter, 1973 \\
\hline Crustacea & Thamnocephalus platyurus & 13 years & Dexter, 1973 \\
\hline Crustacea & Streptocephalus proboscideus & 6 years & Brendonck and Persoone, 1993 \\
\hline Crustacea & Macrobiotus sp. & 7 years & Baumann, 1922 \\
\hline Crustacea & Branchinecta lindahli & 4 years & Donald, 1983 \\
\hline Collembola & Folsomides variabilis & several months & Poinsot, 1968 \\
\hline Tardigrade & Ramazzottius oberhaeuseri & 9 years (eggs) & Guidetti and Jönsson, 2002 \\
\hline Tardigrade & Ramazzottius oberhaeuseri & 4.4 years & Bertolani et al., 2004 \\
\hline Tardigrade & Echiniscu spp. & 3 years & Bertolani et al., 2004 \\
\hline Tardigrade & Adorybiotus coronifer & 8 months & Westh and Ramløv, 1991 \\
\hline Rotifer & Mniobia sp. & 9 years (eggs) & Guidetti and Jönsson, 2002 \\
\hline Rotifer & Mniobia magna & 2.5 years & Rahm, 1923 \\
\hline Rotifer & Mniobia russeola & 2.5 years & Rahm, 1923 \\
\hline Rotifer & Macrotrachela musculosa & $2-3$ months & Rahm, 1923 \\
\hline Nematode & Tylenchus polyhypnus & 39 years & Steiner and Albin, 1946 \\
\hline Nematode & Anguina tritici & 32 years & Fielding, 1951; Norton, 1978; Womersley, 1980 \\
\hline Nematode & Globodera rostochiensis & 25 years & Norton, 1978 \\
\hline Nematode & Ditylenchus dipsaci & 23 years & Perry, 1977; Norton, 1978; Wharton, 1996 \\
\hline Nematode & Panogrolaimus sp. & 8 years & Aroian et al., 1993 \\
\hline Nematode & Heterodera glycines & 6 years & Norton, 1978 \\
\hline Nematode & Heterodera avenae & 5.5 years & Norton, 1978 \\
\hline Nematode & Anguina agrostis & 4 years & Norton, 1978; Preston and Bird, 1987 \\
\hline Nematode & Ditylenchus triformis & 2.5 years & Norton, 1978 \\
\hline Nematode & Aphelenchus avenae & 2.2 years & Crowe and Madin, 1974; Higa and Womersley, 1993 \\
\hline Nematode & Acrobeloides nanus & 1 year & Nicholas and Stewart, 1989 \\
\hline Nematode & Panagrellus silusiae & 1 year & Lees, 1953; Womersley et al., 1998 \\
\hline Nematode & Pratylenchus penetrans & 11 months & Norton, 1978 \\
\hline
\end{tabular}


gradually decreases with increase in the anhydrobiotic period: the maximum period for which the species can survive may be 10 years (Keilin, 1959). Many anhydrobiotic organisms can survive for more than a year, whereas many species of nematodes can stand only 1 or several days at $0 \%$ R.H. Both groups could be also regarded as anhydrobiosis from Keilin's definition (metabolism is almost completely ceased even transiently). The variation in survival period between anhydrobiotic animals seems to depend more on the rate of water loss they can tolerate than on the absolute degree of desiccation stress they can survive (Wharton, 2002a).

Anhydrobiotic organisms can express extremely high tolerances against various kinds of stresses. Gavaret (1859) showed that rotifers and tardigrades could survive being kept in a vacuum. Artemia cysts are usually preserved by vacuum and nitrogen gas pack to maintain high recovery rates. Anhydrobiotic tardigrades can tolerate extreme temperatures ranging from -270 to $+151^{\circ} \mathrm{C}$, immersion in saturated brine and organic solvents and extremely high hydrostatic pressure (600 MPa) (Doyère, 1842; Rahm, 1923, 1937; Becquerel, 1950; Keilin, 1959; Seki and Toyoshima, 1998). The anhydrobiotic chironomid, Po. vanderplanki, also revives after exposure to -270 to $+103^{\circ} \mathrm{C}$ and submersion in pure ethanol and glycerol (Hinton, 1951, 1960a, b, 1968).

A tardigrade, Macrobiotus areolatus, tolerates exposure to $570,000 \mathrm{R}$ ( $\fallingdotseq 5.5 \mathrm{kGy}$ ) of X-ray (May et al., 1964) and 50\% of Artemia cysts can hatch after irradiation at $500 \mathrm{krad}(\fallingdotseq 5 \mathrm{kGy})$ of ${ }^{60} \mathrm{Co} \gamma$-ray (Iwasaki, 1964). Anhydrobiotic larvae of Po. vanderplanki can recover even after $9 \mathrm{kGy}$ of ${ }^{60} \mathrm{Co} \gamma$ ray (Watanabe et al., 2006). The $\mathrm{LD}_{50}$ values for such anhydrobiotic invertebrates are extremely high in comparison with those for vertebrates such as humans and mice (less than $7 \mathrm{~Gy}$ ) (Hirano, 1964; National Astronomical Observatory, 2004). Furthermore, cell lines from lepidopteran insects that do not have desiccation tolerance express much higher resistance to radioactivity than those from mammals: Sf9 and TN368 lepidopteran cell lines can proliferate after 200 Gy of gamma irradiation and can survive 18 to 20 days after 800 Gy of X-ray irradiation, respectively (Koval, 1984; Chandna et al., 2004). The physiological reasons for large difference of the resistance between inver- tebrates and vertebrates remains unclear, although several hypotheses have been proposed, for example, small sizes of body, cells, chromosomes, and genome, composition and structure of membranes, a protective role of cuticle and large amounts of radio-protective chemicals such as cystein and glutathione in the hemolymph (Hirano, 1964; Koyama, 2001).

\section{ADAPTATIONS CONTROLLING RATE OF WATER LOSS}

Many anhydrobiotic animals must slow down and control the rates of evaporative water loss. Anhydrobiotic nematodes can be divided into two groups: fast-dehydration and slow-dehydration strategists (Womersley, 1987; Wharton, 2002a). The fast-dehydration strategists can survive relatively high rates of dehydration or possess adaptations that slow down the rate of water loss. Only a few species of nematodes including Ditylenchus phyllobius, Di. dipsaci, Anguina tritici and Plectus sp. are classified in the former group. The majority of anhydrobiotic animals including both fast and slow-dehydration strategists have evolved behavioral, morphological, physiological and physical adaptations to reduce water loss.

Anhydrobiotic tardigrades always contract into a structure resembling a small "tun" when dehydrated (Sømme, 1995; Wright, 2001). The most conspicuous morphological changes are longitudinal contraction of the trunk and invagination of the legs and intersegmental cuticle. Similar behaviors are also observed in dehydrating bdelloid rotifers (Womerlsley, 1988). The rates of water loss and transpiration gradually decrease as the surface area is reduced during tun formation (Wright et al., 1992). Both rates rapidly decline just after completion of tun formation, finally to an undetectable level. When tardigrades are desiccated at a low relative humidity or under anoxia they cannot form tun and be revived (Crowe, 1972). Thus, tun formation is important for the successful induction of anhydrobiosis in tardigrades.

Nematodes have several behavioral adaptations for induction of anhydrobiosis (Wharton, 2002a). The most common behavioral strategies for decreasing the rate of water loss are coiling and clumping (aggregation). Coiling in Aphelenchus avenae decreases the rate of water loss by decreas- 
ing the external surface of the body, enabling these nematodes to enter anhydrobiosis (Crowe and Madin, 1974). A relationship between coiling and dehydrated quiescent survival has been shown in a desiccation-tolerant nematode, $R$. reniformis, that is not a true anhydrobiosis (Womersley and Ching, 1989). Forms of aggregation by nematodes also decrease water loss. Juvenile stage 2 (J2s) of An. tritici and An. agrostis form a tightly packed large aggregation, without coiling, inside a gall because of space restrictions (Womersley et al., 1998). All anhydrobiotic juveniles and adults undergo coiling in a large aggregation in the gall-forming nematode, An. amsinckiae (Womersley et al., 1998). The rate of successful induction for anhydrobiosis is high in nematodes in the center of the aggregation in $D i$. dispaci (Ellenby, 1969): the dead bodies of juvenile stage $4(\mathrm{~J} 4 \mathrm{~s})$ on the outside provide a barrier against the environment.

Larvae of the chironomid, P. vanderplanki, usually live in tubular soil nests in rock pools (Hinton, 1951). When the pools dry up, the larvae gradually dry out and their bodies fold in the middle inside the soil tubes which they construct from soil and detritus with their saliva. The tubes contribute to decrease the rate of loss of water from the larvae (Kikawada et al., 2005). Body folding adaptations inside the larval tubes in chironomids may also give mechanical protection for freezing (Danks, 1971) and probably for avoiding the mechanical damages in long-dormant dehydrated larvae of $P$. vanderplanki (Hinton, 1951, 1968). However, the folded larval form is not essential at least for induction of anhydrobiosis in this insect, because larvae dehydrated on wet filter paper in a glass Petri dish are often unfolded, and can recover after rehydration (Watanabe et al., 2002).

One physiological strategy for decreasing the rate of water loss is to change the permeability of the body surface (Wharton, 2002a). Di. dipsaci decreases water loss by rapidly lowering body surface permeability $2 \mathrm{~min}$ after the onset of desiccation (Wharton, 1996). This occurs via a phase change in the composition of the epicuticle or a decrease in the thickness of the cuticle (Wharton and Lemmon, 1998). A similar adaptation for decreasing water loss is also suggested for J2s of An. tritici (Ellenby, 1969). Unhatched J2s of G. rostochiensis lose water more slowly than other stages of eggs because of lower permeability of the eggshells (El- lenby, 1969).

Physical adaptations to control evaporative water loss are the most powerful and critical means for successful induction of anhydrobiosis. Free-living nematodes and free-living stages of plant-parasitic nematodes show little adaptation against water loss, because slow dehydration is assured by the physical nature of the soil in most cases (Womersley et al., 1998). The lower soil layer represents a stable environment, whereas the rate of water loss depends upon the characteristics in the upper soil layer. A tubular nest made by soil and detritus decreases the rate of larval water loss during desiccation in Po. vanderplanki, which assures successful induction of anhydrobiosis (Kikawada et al., 2005). Many plant-parasitic nematodes enter anhydrobiosis within the host-plant tissues such as shoots and galls, which provide a physical barrier for delaying water loss. Retention of moulted juvenile cuticles slows the rate of water loss in a plant-parasitic nematode, Rotylenculus reniformis, and in animalparasitic nematodes at infective stages (Evans and Perry, 1976; Gaur and Perry, 1991). Eggshell, cysts and a gelatinous matrix allow slow dehydration in eggs and unhatched J2s of cyst nematodes (Ellenby, 1969). The gelatinous matrix or the egg sac probably decreases water loss from eggs of many root-knot nematodes. An extracuticular subcrystalline layer may play a role in decreasing water loss in M. charis (Demeure and Freckman, 1981).

\section{ACCUMULATION OF TREHALOSE AND ITS PROTECTIVE ROLES}

Trehalose is known as a common compatible solute accumulating in anhydrobiotic organisms, such as unicellular organisms (bacteria, yeast and spores of fungi), invertebrates (chironomids, tardigrades, nematodes and encysted Artemia) and resurrection plants (Yancey et al., 1982; Vertucci and Farrant, 1995; Ingram and Bartels, 1996; Chandler and Bartels, 1999; Clegg, 2001; Watanabe et al., 2002; Tunnacliffe and Lapinski, 2003), whereas other disaccharides, mainly sucrose, are present in seeds and pollen grains of higher plants (Crowe and Clegg, 1973; Elbein, 1974; Ingram and Bartels, 1996; Majara et al., 1996; Behm, 1997; Crowe et al., 1997; Goddijin and van Dun, 1999; Alpert, 2000). Most of these organisms accumulate quite a large amount of trehalose during dehydration, 
about $10-20 \%$ of the dry body weight. For example, nematodes of Ap. avenae and An. tritici accumulate $11-13 \%$ trehalose $/ 5 \%$ glycerol and $9 \%$ trehalose $/ 0.8 \%$ inositol, respectively (Madin and Crowe, 1975; Womersley and Smith, 1981). Encysted embryos of Ar. salina also accumulate 15-18\% trehalose and 2\% glycerol (Clegg, 1962, 1965, 1997). A chironomid, Po. vanderplanki, increases trehalose content from $0.5 \%$ to $20 \%$ of dry body weight during desiccation over $48 \mathrm{~h}$ (Watanabe et al., 2003). A tardigrade, Adorybiotus coronifer, accumulates trehalose from $0.1 \%$ up to $2.3 \%$ within $7 \mathrm{~h}$ of desiccation treatment (Westh and Ramløv, 1991). On the other hand, both growing and desiccated plants of Selaginella lepidophylla (resurrection plants) contain a large amount of trehalose with a small amount of sucrose (Adams et al., 1990). There was a close positive correlation between the trehalose content and viability after rehydration in yeast (Sakurai, 2001).

The characteristics and properties of trehalose and its possible protective roles in anhydrobiosis listed in Table 2 may explain why trehalose is used as the compatible solute in anhydrobiotic organisms ranging from unicellular organisms to higher invertebrates and plants (Ring and Danks, 1998). Trehalose has high solubility, low reactivity, and low tendency to crystallize. It is a non-reducing sugar, and so is less harmful to cells and tissues than reducing sugars such as glucose even at extremely high concentrations. Among sugars and polyols, trehalose provides the most effective protection against desiccation because of its high ability for water-replacement and glass formation (vitrification) (Burke, 1986; Crowe et al., 1987, 1998; Green and Angell, 1989; Franks et al., 1991; Levine and Slade, 1992; Sano et al., 1998): it substitutes for bound and free water, and so maintains the structures of cell membranes and proteins. Structuring of intracellular water induced by trehalose and/or heat shock proteins is essential for high resistance to water stress in yeast cells (Sakurai et al., 1999). The glassy state of trehalose may fill the spaces in tissues during dehydration and allow the orderly packing of body components, which prevents structural damage efficiently, and inhibits aggregation of biological molecules and increase in solute concentration. High and stable viscosity of trehalose glasses also stops all chemical reactions that require molecular diffusion. Tre-
Table 2. Superior characteristics and properties of trehalose

Non-reducing activity
Low tendency to crystallize
Stable glass formation
High vitrification temperature
High ability of water replacement
Structuring activity of intracellullar water with HSP
Stabilization of dry membranes
Antioxidant activity of protein and fatty acids
Free-radical scavenger

Some possible properties are added to the table in Ring and Danks (1998).

halose has a higher glass transition temperature $\left(\mathrm{T}_{\mathrm{g}}\right)$ than other monosaccharides and disaccharides. High $\mathrm{T}_{\mathrm{g}}$ would be important for stabilizing the glass and hence maintaining a stable anhydrobiotic state. For example, anhydrobiotic larvae of Po. vanderplanki spend the dry season in dry mud and detritus in transitional rock pools in Africa and might be exposed to 60 to $70^{\circ} \mathrm{C}$ during the day (Hinton, 1951).

Trehalose stabilizes biological membranes and liposomes. In membranes dried with trehalose at concentrations near those found in anhydrobiotic organisms, morphological damage including vesicle fusion is completely inhibited during drying (Mouradian et al., 1984). Trehalose is the most efficient molecule for dry preservation of membranes, because trehalose acts as a protectant for dry preservation at lower concentrations than do other disaccharides (Rudolph and Cliff, 1990; Rudolph et al., 1990; Crowe et al., 1992). The stabilizing effect of trehalose on phospholipid bilayers might be the result of direct interaction between $-\mathrm{OH}$ groups on the trehalose and the phosphate of membrane phospholipids (Crowe et al., 1987, 1988, 1989; Quinn, 1989; Tsvetkov et al., 1989). Crowe et al. (1992) emphasized the importance of temperature-dependent inhibition of phase transition of dry phospholipid bilayers by trehalose. Phospholipid bilayers are in liquid crystalline phase at room temperature when the lipids are fully hydrated. Lipids dehydrated with trehalose keep the liquid crystalline phase, but those dehydrated without trehalose change into the gel phase. The dry bilayers in the gel phase would leak during rehydration. Thus, trehalose would prevent this leakage by depressing melting point $\left(\mathrm{T}_{\mathrm{m}}\right)$ of the dry lipids (Crowe et al., 1986; Crowe and Crowe, 
1988). These properties could keep cell membranes stable during dehydration-rehydration events.

Trehalose also stabilizes labile proteins during dehydration (Carpenter et al., 1987; Carpenter and Crowe, 1989). It is effective at stabilizing the protein such as phosphofructokinase (PFK) during extreme dehydration (Crowe et al., 1992), whereas other non-reducing compounds such as glycerol, and reducing sugars such as glucose, are not in themselves sufficient for stabilizing the protein (Crowe et al., 1990). Trehalose appears to interact directly with the dry protein, probably by hydrogen bonding of $-\mathrm{OH}$ groups to polar residues in the protein (Carpenter and Crowe, 1989). Trehalose also could efficiently inhibit harmful oxidation of proteins and unsaturated fatty acids in the dry state (Benaroudj et al., 2001; Oku et al., 2003, 2005).

Thus, trehalose may have various protective roles for stabilizing proteins and membranes, and the ability may be important for stable long-term maintenance of anhydrobiosis. However, much of the protective roles have been still theoretical, and the various theories should be clearly demonstrated in vivo in anhydrobiotic organisms.

On the other hand, Higa and Womersley (1993) reported that the accumulation of trehalose in itself is not sufficient for the induction of anhydrobiosis in Ap. avenae. Individuals with a wide variation of trehalose content ranging from $3 \%$ to $16 \%$ per dry weight cannot survive direct exposure to low humidity in Di. myceliophagus (Womersley and Higa, 1998). In Po. vanderplanki, all or most larvae with a relatively large amount of trehalose produced after quick desiccation for 0.5 to 1.5 day can not recover after rehydration (Watanabe et al., 2003; Watanabe, unpublished data). These results suggest that trehalose accumulation may be important for preliminary preparation for anhydrobiotic survival, but is not the only factor associated with induction of cryptobiosis. In fact, anhydrobiotic rotifers, Philodina roseola and Adineta vaga, do not accumulate trehalose nor any other low-molecular weight carbohydrates during dehydration (Lapinski and Tunnacliffe, 2003).

\section{OTHER MOLECULES POTENTIALLY IN- VOLVED IN INDUCTION OF ANHYDRO- BIOSIS}

Several families of heat shock proteins (HSP) serve as molecular chaperones. They participate in unfolding and relocalization of proteins damaged by stresses, assist the folding of newly synthesized proteins, protect them from denaturation and aggregation and aid in their renaturation, and influence the final intracellular location of mature proteins (Jakob et al., 1993; Parsell and Lindquist, 1993; Ellis and Hartl, 1999; Feder and Hoffmann, 1999; Ellis, 2000; MacRae, 2000). Because HSPs are involved in tolerance against various stresses such as low and high temperatures, oxidation, anoxia and heavy metals, they have been thought to have some protective roles in anhydrobiotic organisms. In fact, kinds of small HSP, p26 and artemin, may be involved in stress resistance in Artemia cysts (Willsie and Clegg, 2001, 2002; Chen et al., 2003; Collins and Clegg, 2004; Qiu et al., 2004; Warner et al., 2004). p26 appears to act synergistically with trehalose in vitro (Viner and Clegg, 2001).

Accumulation of late-embryogenesis-abundant (LEA) proteins was often reported in plant seeds and tissues of resurrection plants, associated with acquisition of desiccation tolerance during maturation (Vertucci and Farrant, 1995; Ingram and Bartels, 1996; Chandler and Bartels, 1999; Cuming, 1999; Scott, 2000; Clegg, 2001). Expression of LEA is induced by drought, low temperature and high salt (Ingram and Bartels, 1996; Cuming, 1999), and confers increased osmotic or freezing tolerance in yeast, Saccharomyces cerevisiae (Imai et al., 1996; Honjoh et al., 1999; Zhang et al., 2000). A barley LEA improves drought tolerance in transgenic plants including rice and wheat $(\mathrm{Xu}$ et al., 1996; Sivamani et al., 2000). LEA-like protein (HSP12) is also suggested to be involved in protection of membrane proteins (Sales et al., 2000). Group 3 LEA proteins homologues were found in the nematodes, Caenorhabditis elegans and Steinernema feltiae, the anhydrobiotic nematode, A. avenae, and the prokaryotes Deinococcus radiodurans, Bacillus subtilis and Haemophilus influenzae (Solomon et al., 2000; Dure, 2001; Browne et al., 2002).

All groups of LEA proteins (1, 2, 3 and 6) have 
been thought to act as molecular chaperones (Imai et al., 1996; Wise and Tunnacliffe, 2004). Wise and Tunnacliffe (2004) proposed a possible function of LEA proteins (group 3) during induction of anhydrobiosis; natively unfolded LEA proteins exhibit a strong $\alpha$-helical component during desiccation. The superhelical structures form coils and filaments associated with the cytoskeleton, and finally generate intracellular filament networks within the dehydrating cells. This configuration might increase mechanical strength. LEA proteins also act synergistically with trehalose as an aggregation protectant for several kinds of enzymes (Goyal et al., 2005).

HSPs and LEA proteins have been found in broad taxa of anhydrobiotic organisms from plants to invertebrates, and seem to have important roles on induction and maintenance of anhydrobiosis. However, the protective roles have not been demonstrated in anhydrobiotic organisms including invertebrates. Further analysis of the behavior of proteins during water stress is required to elucidate the function of LEA proteins in vivo during anhydrobiosis.

\section{MECHANISM OF INDUCTION OF ANHY- DROBIOSIS}

Many temperate insects enter diapause in various developmental stages in order to survive adverse conditions. The brain is the common prime regulator of larval, pupal and adult diapause (Denlinger, 1985). On the other hand, anhydrobiosis in Po. vanderplanki larvae occurs without the brain: larvae without a head accumulate relatively large amounts of trehalose during desiccation and recover after rehydration like intact larvae (Fig. 2) (Watanabe et al., 2002). Furthermore, body parts mainly consisting of fat body tissues can synthesize a large amount of trehalose during desiccation, and the fat body can recover after long-term drypreservation (Fig. 3) (Watanabe et al., 2005). Therefore, the central nervous system is not involved in the induction of anhydrobiosis, and individual cells and tissues themselves could enter the anhydrobiotic state in this chironomid.

Trehalose content in anhydrobiotic organisms ranges from $2 \%$ in tardigrades to $40 \%$ in yeast. Trehalose cannot easily enter cells and tissues because of the relatively large molecular size of this disaccharide. Importance of intracellular trehalose during dehydration has been suggested, but internal location of trehalose in anhydrobiotic invertebrates remains unclear. Recently it has been shown that the presence of intracellular trehalose at high level contributes to increase of desiccation tolerance in vertebrate cells: human primary fibroblasts intracellularly producing trehalose, due to a recombinant adenovirus vector, could be maintained in a completely dry state, although the period for dry preservation did not exceed 3 days (Guo et al., 2000). These cells accumulated only $1 \mathrm{~mm}$ trehalose intracellularly. Freeze-dried human and mammalian platelets (apyrene) could recover after rehydration only when they were loaded intracellularly with a relatively high concentration of trehalose $(20 \mathrm{~mm})$ before freeze-drying (Wolkers et al., 2001, 2002). On the other hand, mouse cells containing $10 \%$ trehalose, through expressing trehalose phosphate synthase (TPS) intracellularly, cannot survive complete desiccation, although they have increased tolerance of high osmolarity (Garcia de Castro and Tunnacliffe, 2000). It is not still determined whether the importance of intracellular trehalose reported in vertebrate cells is applicable in cells, tissues and individuals of invertebrates at the anhydrobiotic state.

Different kinds of cells and tissues in larvae of Po. vanderplanki do not all behave the same during induction of anhydrobiosis. The larvae have a large amount of glycogen in their fat body in the hydrated state and a large amount of trehalose in their hemolymph just prior to complete dehydration (Watanabe et al., unpublished data). Because a large amount of intracellular trehalose may be important for induction of anhydrobiosis at the cellular level, all the tissues except for the fat body, including brain, neurons, muscles, alimentary canal and hormone-producing organs such as prothoracic glands and corpora allata, would need a mechanism for rapid intake of trehalose from the hemolymph. The mechanisms for rapid intake of trehalose remain unknown, although sugar transporters can move sugars from the outside to the inside of cells and vice versa (Ehrmann et al., 1998; Jespersen et al., 1999; Truernit, 2001; Guo et al., 2005). Study of the location of intra- and extra-cellular trehalose in anhydrobiotic larvae would provide important information for induction of anhydrobiosis in higher invertebrates. 

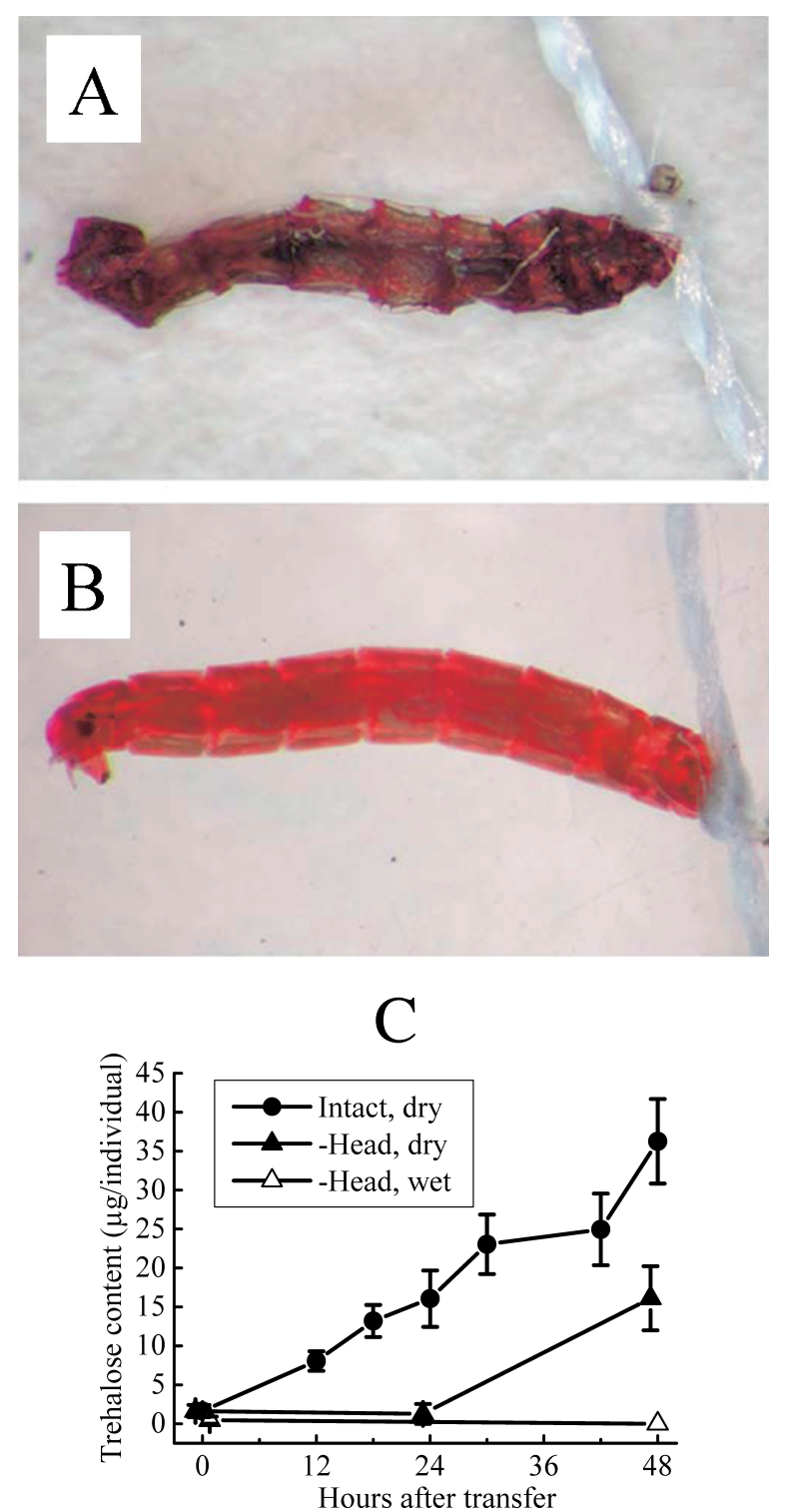

Fig. 2. Recovery and trehalose content of decapitated anhydrobiotic larva of Po. vanderplanki. (A) Decapitated anhydrobiotic larva. (B) Decapitated larva after rehydration. (C) Change of trehalose level during desiccation. Intact, dry: dehydrated intact larvae, -Head, dry: dehydrated decapitated larvae, -Head, wet: decapitated larvae in water. Photographs and data from Watanabe et al. (2002).

Carbon sources for the solutes that protect against desiccation are consistent in unicellular organisms and plants, i.e., mainly glucose in the former and sucrose in the latter (Ingram and Bartels, 1996). By contrast, in insects, glycogen is the main source, and it is stored in the fat body (Storey and Storey, 1991). The distribution of newly synthesized trehalose to all cells and tissues, probably

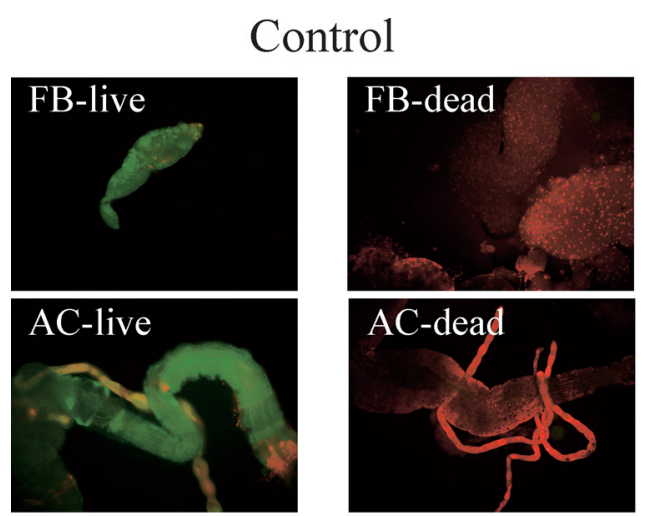

\section{Dry preserved tissues}
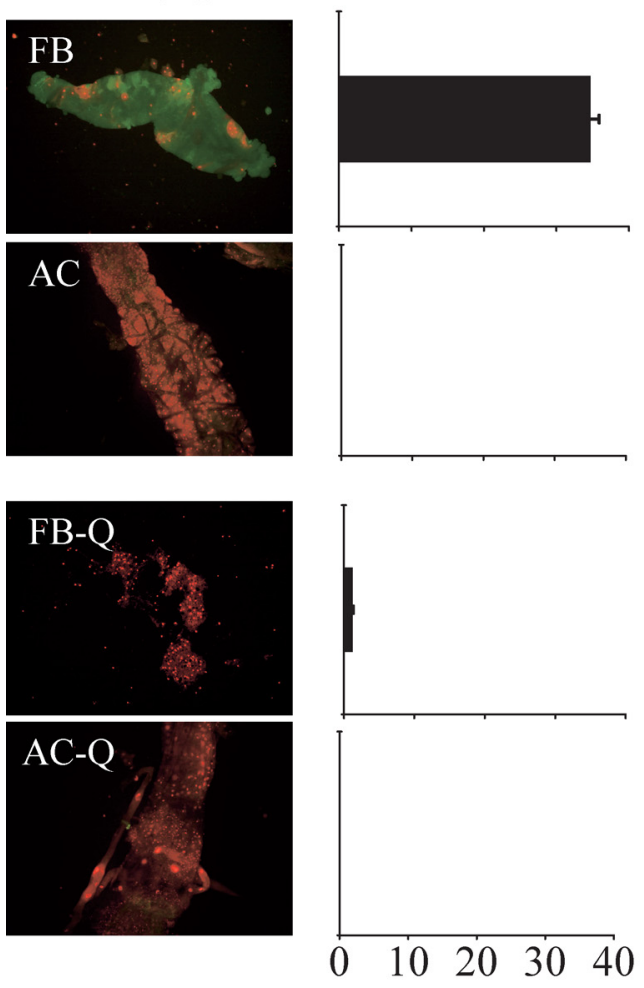

Trehalose content $(\mu \mathrm{g})$

Fig. 3. Fluorescence micrographs and trehalose content of fat body and alimentary canal tissue from Po. vanderplanki larva. The tissue samples were doubly stained with carboxyfluorecein diacetate succinimidyl ester (CFSE) and propidium iodide (PI). Tissue from an intact live larva (FB-live, AC-live); tissue from a dead larva (FB-dead, AC-dead); fat body and alimentary canal desiccated over 2 days (FB, AC) and quickly desiccated within 1 day (FB-Q, AC-Q). Reproduced from Watanabe et al. (2005) with permission of elsevier.

from the fat body via the hemolymph, is likely to be important for dehydrating larvae.

What is the initial signal involved in induction of trehalose synthesis? Organisms usually lose water 

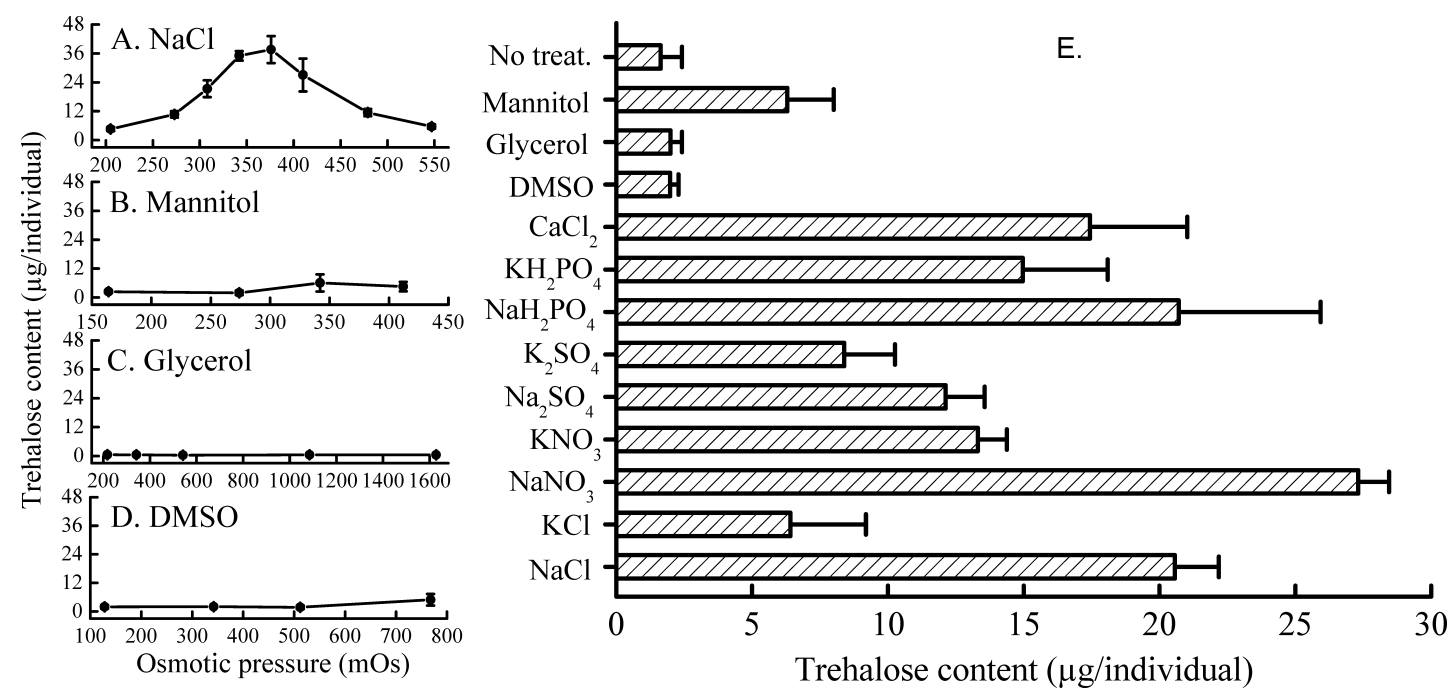

Fig. 4. Trehalose content of Po. vanderplanki larvae incubated for 1 day in various solutions. (A) $\mathrm{NaCl}$, (B) mannitol, (C) glycerol and (D) DMSO solutions at various osmotic pressures. (E) various salt solutions of the same osmotic pressure (342 mOs). Data from Watanabe et al. (2003).

under dry conditions. Such water loss causes an increase of internal osmolarity in multicellular organisms, exposing cells and tissues to high extracellular osmolarity. Decrease of water content therefore has been thought to be the initial signal that switches on the signal transduction pathways leading to the synthesis of trehalose and other compatible substances. Decrease of water content as the first signal is common among anhydrobiotic organisms from plants to invertebrates, but the following responsive molecules may be different. In resurrection plants, cessation of water supply to the root system induces increase of abcissic acid (ABA) (Scott, 2000). Abcissic acid seems to have a major role in initiating signal transduction for the stress response in plants (Vertucci and Farrant, 1995; Ingram and Bartels, 1996; Chandler and Bartels, 1999). Signal transduction pathways for synthesis of compatible solutes in response to desiccation and high osmotic stresses have been demonstrated in the yeast, $S$. cerevisiae; exposure to high extracellular osmolarity induced a twocomponent osmosensor (Sln1 and Sho1) to activate the high osmolarity glycerol (HOG) and mitogenactivated protein (MAP) kinase cascades, and finally caused accumulation of glycerol (Maeda et al., 1994, 1995; Posas et al., 1996; Posas and Saito, 1997; Raitt et al., 2000). This activation response was induced by high osmolarity regardless of the kinds of solute (Maeda, 1999). The homologus osmosensor and the following signal transduction pathways were also found in a higher plant, Arabidopsis thaliana (Shinozaki and Yamaguchi-Shinozaki, 1997; Miyata et al., 1998; Mizoguchi et al., 1998; Urano et al., 1998, 1999). Because MAP kinase cascades are genetically conserved in unicellular organisms, plants, invertebrates and vertebrates, the similar signal transduction in response to desiccation may be also common in invertebrates entering anhydrobiosis. However, the mechanisms for sensing stress in an anhydrobiotic chironomid, $P$. vanderplanki, may be different from the osmosensor found in yeast and plants $(A r$. thaliana): the explosive production of trehalose occurred mainly in high concentration $\mathrm{NaCl}$ solutions, but not in the solutions of dimetyl sulfoxide (DMSO), glycerol and mannitol (Fig. 4) (Watanabe et al., 2003). Various salt solutions can trigger trehalose synthesis, and the amount of trehalose production depends on the kinds of cations in solution. These results suggest that increase of internal ion concentrations, probably associated with water loss, activates the following stress response cascades and finally causes accumulation of trehalose in this chironomid. The physiological and molecular basis for sensing internal ion stress remains unknown. 


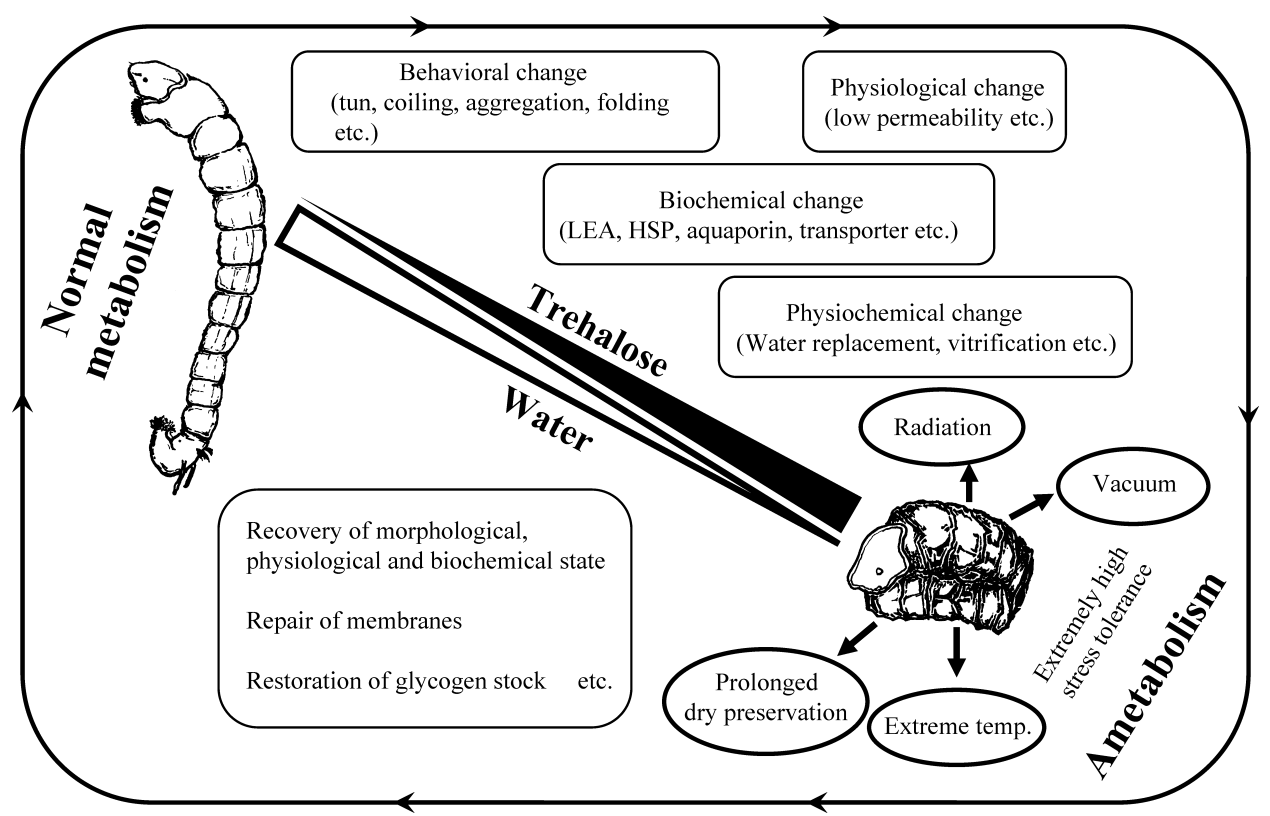

Fig. 5. Biological events occurring during induction of and recovery from anhydrobiosis.

\section{CONCLUSION}

Anhydrobiosis is a particularly stable biological state giving extremely high stress tolerance. Figure 5 summarizes biological events occurring between the normal and the anhydrobiotic states in invertebrates. Organisms require complex behavioral, morphological, physiological and biochemical changes during a relatively short period for successful induction of and recovery from anhydrobiosis, although the adaptations necessary for anhydrobiosis varies among taxa. Unlike unicellular organisms and plants, invertebrates have highly differentiated cells and tissues. In higher invertebrates like Po. vanderplanki, all tissues including the central nervous system can be preserved inside the body in an anhydrobiotic state for at least 17 years.

The group of invertebrates has the largest number of anhydrobiotic species. Each taxa of invertebrates has developed a wide variety of property in anhydrobiosis: Artemia cysts can enter anhydrobiosis only at the embryonic stage, and Po. vanderplanki can do only at the larval stages, whereas tardigrades and rotifers can do at all developmental stages including embryos, juveniles and adults. Behavioral, morphological, physiological and biochemical adaptations are different among anhydrobiotic invertebrates, i.e. a large amount of trehalose at anhydrobiotic state is not found in tardigrades (not large, only $2 \%$ of the dry body weight) and rotifers (undetected level). The period necessary for induction of anhydrobiosis also differs among taxa: tardigrades with low level of trehalose and rotifers without trehalose can enter anhydrobiosis within 1 hour, whereas nematodes and chironomid with a large amount of trehalose take at least 2 days to succeed in entering anhydrobiosis. Understanding the diversity of anhydrobiosis in invertebrates would be a key to elucidate evolutionary scenarios in anhydrobiosis.

\section{ACKNOWLEDGEMENTS}

I thank T. Okuda and T. Kikawada for cooperation and considerable advice on researches of $P$. vanderplanki and $\mathrm{H}$. V. Danks for critical reading of the manuscript. I also thank D. D. Horikawa for providing much useful information about tardigrade anhydrobiosis, and Y. Nakahara, A. Fujita, M. Fujita, Y. Kanamori, A. Saito, S. Hiroyoshi, K. Iwata and M. Suenaga for their helpful advice and encouragements. Two anonymous referees improved the manuscript.

\section{REFERENCES}

Adams, A. (1985) Cryptobiosis in Chironomidae (Diptera)two decades on. Antenna 8: 58-61.

Adams, R. P., E. Kendall and K. K. Kartha (1990) Comparison of free sugars in growing and desiccated plants of Selaginella lepidophylla. Biochem. Syst. Ecol. 18: 107110.

Alpert, P. (2000) The discovery, scope, and puzzle of desiccation tolerance in plants. Plant Ecol. 151: 5-17. 
Aroian, R. V., L. Carta, I. Kaloshian and P. W. Sternberg (1993) A free-living Panagrolainus sp. from Armenia can survive anhydrobiosis for 8.7 years. J. Nematol. 25: $500-502$

Baumann, H. (1922) Die Anabiose der Tardigraden. Zool. Jahrb. 45: 501-556 (in German).

Becquerel, P. (1950) La suspension de la vie au dessous de $1 / 20 \mathrm{~K}$ absolu par demagnetization adiabatique de l'alun de fer dans le vide les plus eléve. C. R. Hebd. Séance. Acad. Sci. Paris 231: 26.

Behm, C. A. (1997) The role of trehalose in the physiology of nematodes. Int. J. Parasitol. 27: 215-229.

Benaroudj, N., D. H. Lee and L. A. Goldberg (2001) Trehalose accumulation during cellular stress protects cells and cellular proteins from damage by oxygen radicals. J. Biol. Chem. 276: 24261-24267.

Bertolani, R., R. Guidetti, K. I. Jönsson, T. Altiero, D. Boschini and L. Rebecchi (2004) Experiences with dormancy in tardigrades. J. Limonol. 63 (Suppl. 1): 16-25.

Brendonck, L. and G. Persoone (1993) Biological/ecological characteristics of large freshwater branchiopods from endorheic regions and consequences for their use in cystbased toxicity tests. In Standardization of Aquatic Toxicity Tests (T. LaPoint and P. W. Greig-Smith eds.). Lewis Publishers, Boca Raton, FL, pp. 7-35.

Browne, J., A. Tunnacliffe and A. Burnell (2002) Anhydrobiosis: plant desiccation gene found in a nematode. $\mathrm{Na}$ ture 416: 38

Burke, M. J. (1986) The glassy state and survival of anhydrous biological systems. In Membranes, Metabolism, and Dry Organisms (A. C. Leopold ed.). Comstock Publishing Associate, Cornell University Press, Ithaca, pp. 358-363.

Carpenter, J. F. and J. H. Crowe (1989) Inframed spectroscopic studies of the interactions of carbohydrates with dried proteins. Biochemistry 28: 3916-3922.

Carpenter, J. F., L. M. Crowe and J. H. Crowe (1987) Stabilization of phosphofructokinase with sugars during freeze-drying: characterization of enhanced protection in the presence of divalent cations. Biochim. Biophys. Acta 923: 109-115.

Chandler, J. and D. Bartels (1999) Plant desiccation. In Plant Responses to Environmental Stresses: From Phytohormones to Genome Reorganization (H. R. Lerner ed.). Marcel Dekker, New York, pp. 575-590.

Chandna, S., B. S. Dwarakanath, R. K. Seth, D. Khaitan, J. S. Adhikari and V. Jain (2004) Radiation responses of Sf9, a highly radioresistant lepidopteran insect cell line. Int. J. Radiat. Biol. 80: 301-315.

Chen, T., R. Amons, J. S. Clegg, A. H. Warner and T. H. MacRae (2003) Molecular characterization of artemin and ferritin from Artemia franciscana. Eur. J. Biochem. 270: $137-145$.

Clegg, J. S. (1962) Free glycerol in dormant cysts of the brine shrimp, Artemia salina, and its disappearance during development. Biol. Bull. 122: 295-301.

Clegg, J. S. (1965) The origin of trehalose and its significance during the emergence of encysted dormant embryos of Artemia salina. Comp. Biochem. Physiol. 14:
$135-143$

Clegg, J. S. (1967) Metabolic studies of encysted embryos of Artemia salina. Comp. Biochem. Physiol. 20: 801-809.

Clegg, J. S. (1978) Hydration-dependent metabolic transitions and the state of cellular water in Artemia cysts. In Dry Biological Systems (J. H. Crowe and J. S. Clegg eds.). Academic Press, New York, pp. 117-153.

Clegg, J. S. (1979) Metabolism and the intracellular environment: the vicinal network model. In Cell-Associated Water (W. Drost-Hansen and J. S. Clegg eds.). Academic Press, New York, pp. 363-413.

Clegg, J. S. (1997) Embryos of Artemia franciscana survive four years of continuous anoxia: the case for complete metabolic rate depression. J. Exp. Biol. 200: 467-475.

Clegg, J. S. (2001) Cryptobiosis - a peculiar state of biological organization. Comp. Biochem. Physiol. 128B: 613624.

Collins, C. H. and J. S. Clegg (2004) A small heat-shock protein, p26, from the crustacean Artemia protects mammalian cells (Cos-1) against oxidative damage. Cell Biol. Intern. 28: 449-455.

Crowe, J. H. (1971) Anhydrobiosis: an unsolved problem. Am. Nat. 105: 563-573.

Crowe, J. H. (1972) Evaporative water loss by tardigrades under controlled relative humidities. Biol. Bull. 142: $407-416$

Crowe, J. H. (1975) The physiology of cryptobiosis in tardigrades. Mem. Ist. Ital. Idrobiol. 32 (Suppl.): 37-59.

Crowe, J. H., J. F. Carpenter and L. M. Crowe (1998) The role of vitrification in anhydrobiosis. Annu. Rev. Physiol. 60: 73-103.

Crowe, J. H., J. F. Carpenter, L. M. Crowe and T. J. Anchordoguy (1990) Are freezing and dehydration similar stress vectors? A comparison of modes of interaction of stabilizing solutes with biomolecules. Cryobiology 27: 219-231.

Crowe, J. H. and J. S. Clegg (1973) Anhydrobiosis. Dowben, Hutchinson \& Ross, Stroundsburg, PA. 477 pp.

Crowe, L. M. and J. H. Crowe (1988) Trehalose and dry dipalmitoylphosphatidylcholine revisited. Biochim. Biophys. Acta 946: 193-201.

Crowe, J. H., L. M. Crowe, J. F. Carpenter, A. S. Rudolph and C. A. Wistrom (1988) Interactions of sugars with membranes. Biochim. Biophys. Acta 947: 367-384.

Crowe, J. H., L. M. Crowe, J. F. Carpenter and C. A. Wistrom (1987) Stabilization of dry phospholipid bilayers and proteins by sugars. Biochem. J. 242: 1-10.

Crowe, J. H., L. M. Crowe and F. A. Hoekstra (1989) Phase transitions and permeability changes in dry membranes during rehydration. J. Bioenerg. Biomembr. 21: 77-91.

Crowe, J. H., L. M. Crowe, S. Petrelski, F. A. Hoelstra, P. D. Araujo and A. D. Panek (1997) Anhydrobiosis: cellular adaptation to extreme dehydration. In Handbook of Physiology. Vol. II (W. H. Dantzler ed.). Oxford University Press, New York, pp. 1445-1477.

Crowe, J. H., F. A. Hoekstra and L. M. Crowe (1992) Anhydrobiosis. Annu. Rev. Physiol. 54: 579-599.

Crowe, J. H. and K. A. C. Madin (1974) Anhydrobiosis in tardigrades and nematodes. Trans. Am. Microscop. Soc. 
93: 513-524.

Crowe, L. M., C. Womersley, J. H. Crowe, D. Reid, L. Appel and A. Rudolph (1986) Prevention of fusion and leakage in freeze-dried liposomes by carbohydrates. Biochim. Biophys. Acta 861: 131-140.

Cuming, A. C. (1999) LEA proteins. In Seed Proteins (P. R. Shewry and R. Casey eds.). Kluwer Academic Publishers, Dordrecht, pp. 753-780.

Danks, H. V. (1971) Overwintering of some north temperate and arctic Chironomidae. II. Chironomid biology. Can. Entomol. 103: 1875-1910.

Danks, H. V. (1987) Insect Dormancy: an Ecological Perspective. Biological Survey of Canada (Terrestrial Arthropods), Ottawa, Canada. 439 pp.

Danks, H. V. (2000) Dehydration in dormant insects. J. Insect Physiol. 46: 837-852.

Demeure, Y. and D. W. Freckman (1981) Recent advances in the study of anhydrobiotic nematodes. In Plant Parasitic Nematodes. Vol. 3 (B. M. Zuckerman, W. F. Mai and R. F. Rohde eds.). Academic Press, New York, pp. 205-226.

Denlinger, D. L. (1985) Hormonal control of diapause. In Comparative Insect Physiology, Biochemistry and Pharmacology. Vol. 8. Endocrinology II (G. A. Kerkut and L. Gilbert eds.). Pergamon Press, Oxford, pp. 353-412.

Dexter, R. W. (1973) Persistence of viability in the eggs of certain phyllopod Crustacea and its ecological significance. Am. Zool. 13: 1341-1342.

Dingle, H. (1996) Migration: The Biology of Life on the Move. Oxford University Press, New York. 474 pp.

Donald, D. B. (1983) Erratic occurrence of anostracans in temporary ponds: colonization and extinction or adaptation to variations in annual weather? Can. J. Zool. 61: 1492-1498.

Doyère, P. L. N. (1842) Memories sur les tardigrades. Sur le facilité que possedent les tardigrades, les rotifers, les anguillules des toits et quelques autres of animalcules, de revenir à la vie après été completement déssechées. Ann. Sci. Nat. (Ser. 2) 18: 5.

Dure, L., 3rd (2001) Occurrence of a repeating 11-mer amino acid sequence motif in diverse organism. Protein Peptide Lett. 8: 115-122.

Edney, E. B. (1977) Water Balance in Land Arthropods. Springer-Verlag, New York. 282 pp.

Ehrmann, M., R. Ehrle, E. Hofmann, W. Boos and A. Schlosser (1998) The ABC maltose transporter. Mol. Microbiol. 29: 685-694.

Elbein, A. D. (1974) The metabolism of trehalose. $A d v$. Carbo. Chem. Biochem. 30: 227-256.

Ellenby, C. (1969) Dormancy and survival in nematodes. Symp. Soc. Exp. Biol. 23: 83-97.

Ellis, R. J. (2000) Chaperone substrates inside the cell. Trends Biochem. Sci. 25: 210-212.

Ellis, R. J. and F. U. Hartl (1999) Principles of protein folding in the cellular environment. Curr. Opin. Struct. Biol. 9: $102-110$.

Evans, A. A. F. and R. N. Perry (1976) Survival strategies in nematodes. In The Organization of Nematodes (N. A. Croll ed.). Academic Press, New York, pp. 383-424.

Feder, M. E. and G. E. Hoffmann (1999) Heat-shock pro- teins, molecular chaperones, and ecological physiology. Annu. Rev. Physiol. 61: 243-282.

Fielding, M. (1951) Observations on the length of dormancy in certain plant infesting nematodes. Proc. Helminthol. Soc. Wash. 18: 110-112.

Franceschi, T. (1948) Anabiosi nei tardigdi. Boll. Mus. Ist. Biol. Univ. Genova 22: 47-49.

Franks, F., R. H. M. Hatley and S. F. Mathias (1991) Materials science and the production of shelf stable biologicals. BioPharm October: 38-42.

Garcia de Castro, A. and A. Tunnacliffe (2000) Intracellular trehalose improved osmotolerance but not desiccation tolerance in mammalian cells. FEBS Lett. 487: 199-202.

Gaur, H. S. and R. N. Perry (1991) The biology and control of the plant parasitic nematode Rotylenchulus reniformis. Agric. Zool. Rev. 4: 177-212.

Gavaret, J. (1859) Quelques expériences sur les rotifères, les tardigrades et les anguillules des mousses des toits. Ann. Sci. Nat. (Ser. 4) 11: 315.

Goddijin, O. J. M. and K. van Dun (1999) Trehalose metabolism in plants. Trends Plant Sci. 4: 315-319.

Goyal, K., L. J. Walton and A. Tunnacliffe (2005) LEA proteins prevent protein aggregation due to water stress. Biochem. J. 388: 151-157.

Green, J. L. and C. A. Angell (1989) Phase relations and vitrification in saccharide-water solutions and the trehalose anomaly. J. Phys. Chem. 93: 2880-2882.

Guidetti, R. and K. I. Jönsson (2002) Long-term anhydrobiotic survival in semi-terrestrial micrometazoans. $J$. Zool. 257: 181-187.

Guo, N., I. Puhlev, D. R. Brown, J. Mansbridge and F. Levine (2000) Trehalose expression confers desiccation tolerance on human cells. Nature Biotechnol. 18: 168-171.

Guo, X., M. Geng and G. Du (2005) Glucose transporter 1, distribution in the brain and in neural disorders: its relationship with transport of neuroactive drugs through the blood-brain barrier. Biochem. Genet. 43: 175-187.

Hadley, N. F. (1994) Water Relations of Terrestrial Arthropods. Academic Press, New York. 356 pp.

Hairston, N. G., R. A. Van Brunt, Jr. and C. M. Kearns (1995) Age and survivorship of diapausing eggs in a sediment egg bank. Ecology 76: 1706-1711.

Higa, L. M. and C. Z. Womersley (1993) New insights into the anhydrobiotic phenomenon: the effect of trehalose content and differential rates of evaporative water loss on the survival of Aphelenchus avenae. J. Exp. Zool. 267: $120-129$.

Hinton, H. E. (1951) A new chironomid from Africa, the larva of which can be dehydrated without injury. Proc. Zool. Soc. Lond. 121: 371-380.

Hinton, H. E. (1960a) Cryptobiosis in the larva of Polypedilum vanderplanki Hint. (Chironomidae). J. Insect Physiol. 5: 286-300.

Hinton, H. E. (1960b) A fly larva that tolerates dehydration and temperatures of $-270^{\circ} \mathrm{C}$ to $+102^{\circ} \mathrm{C}$. Nature 188 : $336-337$.

Hinton, H. E. (1968) Reversible suspension of metabolism and the origin of life. Proc. R. Soc. Lond. B 171: 43-57.

Hirano, T. (1964) Pest control by radiation. Plant Prot. 18: 
189-195 (in Japanese).

Hochachka, D. W. and M. Guppy (1987) Metabolic Arrest and the Control of Biological Time. Harvard University Press, Cambridge, Massachusetts. 227 pp.

Honjoh, K., Y. Oda, R. Tanaka, T. Miyamoto and S. Hatano (1999) Introduction of the hiC6 gene, which encodes a homologue of a late embryogenesis abundant (LEA) protein, enhances freezing tolerance of yeast. J. Plant Physiol. 155: 509-512.

Imai, R., L. Chang, A. Ohta, E. A. Bray and M. Takagi (1996) A lea-class gene of tomato confers salt and freezing tolerance when expressed in Saccharomyces cerevisiae. Gene 170: 243-248.

Ingram, J. and D. Bartels (1996) The molecular basis of dehydration tolerance in plants. Annu. Rev. Plant Physiol. Plant Mol. Biol. 47: 377-403.

Iwasaki, T. (1964) Sensitivity of Artemia eggs to the gamma irradiation 1. Hatchability of encysted dry eggs. J. Radiat. Res. 5: 69-75.

Jakob, U., M. Gaestel, K. Engel and J. Buchner (1993) Small heat shock proteins are molecular chaperones. J. Biol. Chem. 268: 1517-1520.

Jespersen, L., L. B. Cesar, P. G. Meaden and M. Jakobsen (1999) Multiple alpha-glucoside transporter genes in brewer's yeast. Appl. Environ. Microbiol. 65: 450-456.

Jönsson, K. I. and R. Bertolani (2001) Facts and fiction about long-term survival in tardigrades. J. Zool. 255: 121-123

Keilin, D. (1959) The problem of anabiosis or latent life: history and current concept. Proc. R. Soc. Lond. B 150: 149-191.

Kikawada, T., N. Minakawa, M. Watanabe and T. Okuda (2005) Factors inducing successful anhydrobiosis in the African chironomid, Polypedilum vanderplanki: significance of the larval tubular nest. Integ. Comp. Biol. 45: 710-714.

Koval, T. M. (1984) Multiphasic survival response of a radioresistant lepdopteran insect cell line. Radiat. Res. 98: 642-648.

Koyama, J. (2001) Pest control by radiation. Radiat. Ind. 89: 42-46 (in Japanese).

Lapinski, J. and A. Tunnacliffe (2003) Anhydrobiosis without trehalose in bdelloid rotifers. FEBS Lett. 553: 387-390.

Lees, E. (1953) An investigation into the method of dispersal of Panagrellus silusiae, with particular reference to its desiccation resistance. J. Helminth. 27: 95-103.

Levine, H. and L. Slade (1992) Another view of trehalose for drying and stabilizing biological materials. BioPharm May: 36-40.

MacRae, T. H. (2000) Structure and function of small heat shock/-crystallin proteins: established concepts and emerging ideas. Cell. Mol. Life Sci. 57: 899-913.

Madin, K. A. C. and J. H. Crowe (1975) Anhydrobiosis in nematodes: carbohydrate and lipid metabolism during dehydration. J. Exp. Zool. 193: 335-342.

Maeda, T. (1999) Osmotic response of the yeast Saccharomyces cerevisiae. In Molecular Mechanisms of Response and Adaptation to Environmental Stimuli (K. Shi- nozaki, M. Yamamoto, H. Okamoto and M. Iwabuchi eds.). Kyoritsu Pub., Tokyo, pp. 2206-2213 (in Japanese).

Maeda, T., M. Takazawa and H. Saito (1995) Activation of yeast PBS2 MAPKK by MAPKKKs or by binding of an SH3-containing osmosensor. Science 269: 554-558.

Maeda, T., S. M. Wurgler-Murphy and H. Saito (1994) A two-component system that regulates an osmosensing MAP kinase cascade in yeast. Nature 369: 242-245.

Majara, M., E. S. C. O'Connor-cox and B. C. Axcell (1996) Trehalose - a stress protectant and stress indicator compound for yeast exposed to adverse conditions. J. Am. Soc. Brew. Chem. 54: 221-227.

Marcus, N. H., R. Lutz, W. Burnett and P. Cable (1994) Age, viability and vertical distribution of zooplankton resting eggs from an anoxic basin: evidence of an egg bank. Limnol. Oceanogr. 39: 154-158.

May, R. M., M. Maria and J. Guimard (1964) Action différentielle des rayons $\mathrm{x}$ et ultraviolets sur le tardigrade Macrobiotus areolatus, a l'état actif et desséché. Bull. Biol. France Belgique 98: 349-367.

Miyata, S., T. Urano, K. Yamaguchi-Shinozaki and K. Shinozaki (1998) Characterization of genes for two-component phosphorelay mediators with a single HPt domain in Arabidopsis thaliana. FEBS Lett. 437: 11-14.

Mizoguchi, T., K. Ichimura, K. Irie, P. Morris, J. Giraudat, K. Matsumoto and K. Shinozaki (1998) Identification of a possible MAP kinase cascade in Arabidopsis thaliana based on pairwise yeast two-hybrid analysis and functional complementation tests of yeast mutants. FEBS Lett. 437: 56-60.

Moore, W. G. (1979) The effect of prolonged wet storage on the hatchability of eggs of Streptocephalus seali Ryder (Branchiopoda: Anostraca). Southwest. Nat. 24: 187206.

Mouradian, R., C. Womersley, L. M. Crowe and J. H. Crowe (1984) Preservation of functional integrity during long term storage of a biological membrane. Biochim. Biophys. Acta 778: 615-617.

Nambu, Z., S. Tanaka and F. Nambu (2004) Influence of photoperiod and temperature on reproductive mode in the brine shrimp, Artemia franciscana. J. Exp. Zool. 301A: 542-546.

National Astronomical Observatory (2004) Chronological Scientific Tables 2005. Maruzen, Tokyo, 1015 pp. (in Japanese).

Needham, J. T. (1743) Concerning chalky concretions called malm, with some microscopical observations on the farina of Red Lily, and worms discovered in smuthy corn. Phil. Trans. 42: 634.

Nicholas, W. L. and A. C. Stewart (1989) Experiments on anhydrobiosis in Acrobeloides nanus (De Man, 1880) Anderson 1986 (Nematoda). Nematologica 35: 489-490.

Norton, D. C. (1978) Ecology of Plant-Parasitic Nematodes. John Wiley and Sons, New York. 268 pp.

Oku, K., M. Kurose, M. Kubota, S. Fukuda, M. Kurimoto and Y. Tsujisaka and M. Sakurai (2005) Interaction between trehalose and alkaline-earth metal ions. Biosci. Biotechnol. Biochem. 69: 7-12. 
Oku, K., H. Watanabe, M. Kubota, S. Fukuda, M. Kurimoto, Y. Tsujisaka, M. Komori, Y. Inoue and M. Sakurai (2003) NMR and quantum chemical study on the $\mathrm{OH} \cdots \pi$ and $\mathrm{CH} \cdots \mathrm{O}$ interactions between trehalose and unsaturated fatty acids: implication for the mechanism of antioxidant function of trehalose. J. Am. Chem. Soc. 125: 1273912748 .

Ostran, A. (1998) Factors affecting long-term survival of rotifers: a preliminary study. Hydrobiologia 387/388: 327-331.

Parsell, D. A. and S. Lindquist (1993) The function of heat shock proteins in stress tolerance: degradation and reactivation of damages proteins. Annu. Rev. Gen. 27: 437-496.

Perry, R. N. (1977) Desiccation survival of larval and adult stages of the plant parasitic nematodes, Ditylenchus dispaci and D. myceliophagus. Parasitology 74: 139-148.

Poinsot, N. (1968) Cas d'anhydrobiose chez le Collembole Subisotoma variabilis Gisin. Rev. Écol. Biol. Sol. 4: 585-586.

Posas, F. and H. Saito (1997) Osmotic activation of the HOG MAPK pathway via Ste11p MAPKKK: scaffold role of Pbs2p MAPKK. Science 276: 1702-1705.

Posas, F., S. M. Wurgler-Murphy, T. Maeda, E. A. Witten, T. C. Thai and H. Saito (1996) Yeast HOG1 MAP kinase cascade is regulated by a multistep phosphorelay mechanism in the SLN1-YPD1-SSK1 "two component" osmosensor. Cell 86: 865-875.

Potts, M. (1994) Desiccation tolerance of prokaryotes. Microbiol. Rev. 58: 755-805.

Potts, M. (1999) Mechanisms of desiccation tolerance in cyanobacteria. Eur. J. Phycol. 34: 319-328.

Preston, C. M. and A. F. Bird (1987) Physiological and morphological changes associated with recovery from anabiosis in the dauer larvae of the nematode Anguina agrostis. Parasitology 95: 125-133.

Priestley, D. A. (1986) Seed Aging: Implications for Seed Storage and Persistence in the Soil. Cumstock Publishing Associates, Ithaca, New York. 304 pp.

Qiu, Z., R. I. Viner, T. H. MacRae, J. K. Willsie and J. S. Clegg (2004) A small heat shock protein from Artemia franciscana is phosphorylated at serine 50. Biochim. Biophys. Acta 1700: 75-83.

Quinn, P. J. (1989) Effect of sugars on the phase behaviour of phospholipid model membranes. Biochem. Soc. Trans. 17: 953-957.

Rahm, G. (1923) Biologische und physiologische Beiträge zur Kenntnis der Moosfauna. Z. Allg. Physiol. 20: 1-34.

Rahm, G. (1937) A new ordo of tardigrades from the hot springs of Japan (Furuyu section, Unzen). Annot. Zool. Jpn. 16: 345-352.

Raitt, D. C., F. Posas and H. Saito (2000) Yeast Cdc42 GTPase and Ste20 PAK-like kinase regulate Sho1-dependent activation of the HOG1 MAPK pathway. EMBO J. 19: 4623-4631.

Ricci, C. (1998) Anhydrobiotic capabilities of bdelloid rotifers. Hydrobiologia 387/388: 321-326.

Ring, R. A. and H. V. Danks (1998) The role of trehalose in cold-hardiness and desiccation. Cryoletters 19: 275-
282.

Rudolph, A. S. and R. O. Cliff (1990) Dry storage of liposome-encapsulated hemoglobin: a blood substitute. Cryobiology 27: 585-590.

Rudolph, B. R., E. Chandrasekhar, B. P. Ggaber and M. A. Nagumo (1990) Molecular modeling of saccharidelipid interactions. Chem. Phys. Lipids 53: 243-261.

Sakurai, M. (2001) The mechanism of preservation of dried and freeze-dried biomaterials with trehalose. Cryobiol. Cryotechnol. 47: 19-25 (in Japanese).

Sakurai, M., F. Sano, N. Asakawa and Y. Inoue (1999) Role of intracellular trehalose as a stress protectant of yeast cells No. 2. Cryobiol. Cryotechnol. 45: 149-152 (in Japanese).

Sales, K., W. Brandt, E. Rumbak and G. Lindsey (2000) The LEA-like protein HSP 12 in Saccharomyces cerevisiae has a plasma membrane location and protects membranes against desiccation and ethanol-induced stress. Biochim. Biophys. Acta 1463: 267-278.

Sano, F., N. Asakawa, Y. Inoue and M. Sakurai (1998) Role of intracellular trehalose as a stress protectant of yeast cells. Cryobiol. Cryotechnol. 44: 110-113 (in Japanese).

Schmidt, P. (1948) Anabiosis. U.S.S.E. Acad. Sci., Moscow (in Russian).

Scott, P. (2000) Resurrection plants and the secrets of the leaf. Ann. Bot. 85: 159-166.

Seckbach, J. (1999) Enigmatic Microorganisms and Life in Extreme Environments. Kluwer Academic Publishers, Dordrecht, Netherlands. $687 \mathrm{pp}$.

Seki, K. and M. Toyoshima (1998) Preserving tardigrades under pressure. Nature 395: 853-854.

Shinozaki, K. and K. Yamaguchi-Shinozaki (1997) Gene expression and signal transduction in water-stress response. Plant Physiol. 115: 327-334.

Sivamani, E., A. Bahieldin, J. M. Wraith, T. Al-Niemi, W. E. Dyer, T. D. Ho and R. Qu (2000) Improved biomass productivity and water use efficiency under water deficit conditions in transgenic wheat constitutively expressing the barley HVA1 gene. Plant Sci. 155: 1-9.

Solomon, A., R. Salomon, I. Paperna and I. Glazer (2000) Desiccation stress of entomopathogenic nematodes induces the accumulation of a novel heat-stable protein. Parasitology 121: 409-416.

Sømme, L. (1995) Invertebrates in Hot and Cold Arid Environments. Springer-Verlag, Berlin. 288 pp.

Sømme, L. (1996) Anhydrobiosis and cold tolerance in tardigrades. Eur. J. Entomol. 93: 349-357.

Spallanzani, L. (1776) Opuscoli di Fisica Animale e Vegetabile. Societa Tipografica. (Modena). Vol. 2. pp. 203285.

Steiner, G. and F. E. Albin (1946) Resuscitation of the nematode Tylenchis polyhypnus sp., after almost 39 years' dormancy. J. Wash. Acad. Sci. 36: 97-99.

Storey, K. B. and J. M. Storey (1991) Biochemistry of cryoprotectants. In Insects at Low Temperature (R. E. Lee and D. L. Denlinger eds.). Chapman and Hall, New York, pp. 64-93.

Tauber, M. J., C. A. Tauber and S. Masaki (1986) Seasonal 
Adaptations of Insects. Oxford University Press, New York. 411 pp.

Tomos, D. (1992) Life without water. Curr. Biol. 2: 594-596. Truernit, E. (2001) Plant physiology: the importance of sucrose transporters. Curr. Biol. 11: 169-171.

Tsvetkov, T. D., L. I. Tsonev, N. M. Tsvetkova, R. D. Koynova and B. G. Tenchov (1989) Effect of trehalose on the phase properties of hydrated and lyophilized dipalmitoylphosphatidylcholine multilayers. Cryobiology 26: 162-169.

Tunnacliffe, A. and J. Lapinski (2003) Resurrecting Van Leeuwenhoek's rotifers: a reappraisal of the role of disaccharides in anhydrobiosis. Phil. Trans. R. Soc. Lond. B358: 1755-1771.

Urano, T., B. Yakubov, R. Satoh, K. Yamaguchi-Shinozaki, M. Seki, T. Hirayama and K. Shinozaki (1999) A transmembrane hybrid-type histidine kinase in Arabidopsis functions as an osmosensor. Plant Cell 11: 1743-1754.

Urano, T., B. Yakubov, K. Yamaguchi-Shinozaki and K. Shinozaki (1998) Stress-responsive expression of genes for two-component response regulator-like proteins in Arabidopsis thaliana. FEBS Lett. 427: 175-178.

Van Gundy, S. D. (1965) Factors in survival of nematodes. Annu. Rev. Phytopathol. 3: 43-68.

Van Leeuwenhoek, A. (1702) Letter to Hendrik van Bleysmijk dated 9 Feburary 1702 (in Italian).

Vegis, A. (1964) Dormancy in higher plants. Annu. Rev. Plant Physiol. 15: 185-224.

Vertucci, C. W. and J. M. Farrant (1995) Acquisition and loss of desiccation tolerance. In Seed Development and Germination (J. Kigel and G. Galil eds.). Marcel Dekker, New York, pp. 237-272.

Viner, R. I. and J. S. Clegg (2001) Influence of trehalose on the molecular chaperone activity of p26 a small heat shock protein. Cell Stress Chap. 6: 126-135.

Warner, A. H., R. T. Brunet, T. H. MacRae and J. S. Clegg (2004) Artemin is an RNA-binding protein with high thermal stability and potential RNA chaperone activity. Arch. Biochem. Biophys. 424: 189-200.

Watanabe, M., T. Kikawada, A. Fujita, E. Forczek, T. Adati and T. Okuda (2004) Physiological traits of invertebrates entering cryptobiosis in a post-embryonic stage. Eur. J. Entomol. 101: 439-444.

Watanabe, M., T. Kikawada, A. Fujita and T. Okuda (2005) Induction of anhydrobiosis in fat body tissue from an insect. J. Insect Physiol. 51: 727-731.

Watanabe, M., T. Kikawada and T. Okuda (2003) Increase of internal ion concentration triggers trehalose synthesis associated with cryptobiosis in larvae of Polypedilum vanderplanki. J. Exp. Biol. 206: 2281-2286.

Watanabe, M., T. Kikawada, F. Yukuhiro and T. Okuda (2002) Mechanism allowing an insect to survive complete dehydration and extreme temperatures. J. Exp. Biol. 205: 2799-2802.

Watanabe, M., T. Sakashita, A. Fujita, T. Kikawada, D. D. Horikawa, Y. Nakahara, S. Wada, T. Funayama, N. Hamada, Y. Kobayashi and T. Okuda (2006) Biological effects of anhydrobiosis in an African chironomid, Polypedilum vanderplanki on radiation tolerance. Int. J.
Radiat. Biol. (in press)

Westh, P. and H. Ramløv (1991) Trehalose accumulation in the tardigrade Adorybiotus coronifer during anhydrobiosis. J. Exp. Zool. 258: 303-311.

Wharton, D. A. (1996) Water loss and morphological changes during desiccation of the anhydrobiotic nematode Ditylenchus dispaci. J. Exp. Biol. 199: 1085-1093.

Wharton, D. A. (2002a) Nematode survival strategies. In The Biology of Nematodes (D. L. Lee ed.). Taylor and Francis, London, pp. 389-411.

Wharton, D. A. (2002b) Life at the Limits, Organisms in Extreme Environments. Cambridge University Press, Cambridge. $307 \mathrm{pp}$.

Wharton, D. A. and J. Lemmon (1998) Ultrastructural changes during desiccation of the anhydrobiotic nematode Dithylenchus dispaci. Tissue Cell 30: 312-323.

Willsie, J. K. and J. S. Clegg (2001) Nuclear p26, a small heat shock/alpha-crystallin protein, and its relationship to stress resistance in Artemia franciscana embryos. $J$. Exp. Biol. 204: 2339-2350.

Willsie, J. K. and J. S. Clegg (2002) Small heat shock protein p26 associates with nuclear lamins and hsp70 in nuclei and nuclear matrix fractions from stressed cells. J. Cell. Biochem. 84: 601-614.

Wise, M. J. and A. Tunnacliffe (2004) POPP the question: what do LEA proteins do? Trends Plant Sci. 9: 13-17.

Wolkers, W. F., F. Tablin and J. H. Crowe (2002) From anhydrobiosis to freezing-drying of eukaryotic cells. Comp. Biochem. Physiol. A131: 535-543.

Wolkers, W. F., N. J. Walkers, F. Tablin and J. H. Crowe (2001) Human platelets loaded with trehalose survive freezingdrying. Cryobiology 42: 79-87.

Womersley, C. (1980) The effect of different periods of dehydration/rehydration periods upon the ability of second stage larvae of Anguina tritici to survive desiccation at 0\% relative humidity. Ann. Appl. Biol. 95: 221-224.

Womersley, C. (1981) Biochemical and physiological aspects of anhydrobiosis. Comp. Biochem. Physiol. 70B: 669-678.

Womersley, C. (1987) A re-evaluation of survival strategies used by nematode anhydrobiotes in relation to their natural environment. In Vistas on Nematology (J. A. Veech and D. W. Dickson eds.). Society of Nematologists Inc., Hyattsville, Maryland, pp. 165-173.

Womersley, C. Z. (1988) Morphological and biochemical adaptations to anhydrobiosis in artificially and naturally dehydrated populations of Ditylenchus miceliophagus (Nematoda). Am. Zool. 28: 20.

Womersley, C. Z. and C. Ching (1989) Natural dehydration regimes as a prerequisite for the successful induction of anhydrobiosis in the nematode Rotylenchulus reniformis. J. Exp. Biol. 143: 359-372.

Womersley, C. Z. and L. M. Higa (1998) Trehalose: its role in the anhydrobiotic survival of Ditylenchus myceliophagus. Nematologia 44: 269-292.

Womersley, C. and L. Smith (1981) Anhydrobiosis in nematodes - 1. the role of glycerol myo-inositol and trehalose during desiccation. Comp. Biochem. Physiol. 70B: 579-586. 
Womersley, C. Z., D. A. Wharton and L. M. Higa (1998) Survival biology. In The Physiology and Biochemistry of Free-living and Plant-parasitic Nematodes (R. N. Perry and D. J. Wright eds.). CABI Publishing, Wallingford, pp. 271-302.

Wright, J. C. (1991) The significance of four xeric parameters in the ecology of terrestrial tardigrades. J. Zool. 224: 59-77.

Wright, J. C. (2001) Cryptobiosis 300 years on from van Leuwenhoek: what have we learned about Tardigrades? Zool. Anz. 240: 563-582.

Wright, J. C., P. Westh and H. Ramløv (1992) Cryptobiosis in tardigrada. Biol. Rev. 67: 1-29.
Xu, D., X. Duan, B. Wang, B. Hong, T. Ho and R. Wu (1996) Expression of a late embryogenesis abundant protein gene, HVA1, from barley confers tolerance to water deficit and salt stress in transgenic rice. Plant Physiol. 110: 249-257.

Yancey, P. H., M. E. Clark, S. C. Hand, R. D. Bowlus and G. Somero (1982) Living with water stresses: evolution of osmolytes systems. Science 217: 1214-1222.

Zhang, L., A. Ohta, M. Takagi and R. Imai (2000) Expression of plant group 2 and group 3 lea genes in Saccharomyces cerevisiae revealed functional divergence among LEA proteins. J. Biochem. 127: 611-616. 